\title{
Statistical Assessments of River Flow Alterations and Environmental Flow Standards
}

\author{
Ralph A. Wurbs and Ming-Yue Yang \\ Texas A\&M University, College Station, Texas.
}

\begin{abstract}
A water availability modeling (WAM) system consisting of the Water Rights Analysis Package (WRAP) and input datasets for all Texas river basins has been used for statewide, regional, and operational planning and water allocation regulatory purposes for many years. The modeling system was recently expanded to support integration of environmental flow requirements in comprehensive water management. A strategy is presented in this paper for combining the WRAP-WAM modeling system with data management and statistical analysis tools to expand capabilities for analyzing stream flow alterations and the effects on flows of environmental flow standards. A Trinity River Basin case study demonstrates the utility of the modeling and analysis strategy in addressing relevant issues in the river systems of Texas and elsewhere. Dams and reservoirs constructed on the Trinity River and tributaries supply water for the Dallas-Fort Worth and Houston metropolitan areas, which are among the most rapidly growing large metro areas in the United States. Ecologically relevant statistical analyses of observed flows presented in this paper are designed to quantify flow alterations. Analyses of simulated flows representing natural and specified conditions of development are performed to assess the impacts of both water resources development and the establishment of environmental flow standards.
\end{abstract}

\section{Introduction}

Supplying water, electrical energy and other needs of growing populations and economies while preserving the vitality of riverine ecosystems is a global challenge. Water resources development supporting population and economic growth has altered the natural flow of rivers throughout the world (Gippel et al. 2009; O'Keefe 2012; Paredes-Arquiola et al. 2013; Wohl 2019). The literature investigating flow characteristics necessary for healthy ecosystems is extensive (Jowett 1997; Richter et al. 1997; Tharme 2003; Acreman and Dunbar 2004; Poff and Zimmerman 2009; Gao et al. 2009).

The state of Texas in the United States has experienced continual population and economic growth and accompanying water resources development over the past $100 \mathrm{y}$. A water availability modeling (WAM) system has been implemented during the past $20 y$ to support water allocation, planning, and other endeavours. Integration of environmental flow standards in water management with the WAM system has become a major priority in recent years.

The objective of the research reported in this paper is to improve capabilities for compiling statistical information characterizing stream flows to support integration of environmental flow needs in water management and associated water availability modeling. A modeling and analysis system that combines river system simulation, data management, and statistical methods is explored through simulation analyses of the Trinity River and its tributaries. In addition to expanding modeling capabilities, the case study also provides insight regarding the effects on the flows of a major river system on both large scale urban development and establishment of environmental flow standards.

The paper presents research that (1) quantifies long term alterations in flow characteristics of the Trinity River and tributaries that have occurred over the past 100 y due to population growth and water resources development; (2) analyzes the effects of instream flow standards established pursuant to a statewide program to protect environmental resources; and (3) demonstrates modeling and analysis capabilities that are effective in this investigation and similar studies in other river basins. Methods for performing ecologically relevant statistical analyses of observed flows, naturalized flows, and simulated flows for specified conditions of development are investigated.

The research included compilation, synthesis and analysis of period-of-record daily observed flows and 1940-2018 daily simulated naturalized, regulated and unappropriated flows at relevant sites. Observed flows are daily means of flow rates recorded at gauges. WRAP-WAM naturalized flows are 1940-2018 daily flow rates that would have occurred under natural conditions with minimal or no water resources development and use. The results of a daily WRAP simulation include hydrologic period-of-analysis sequences of daily regulated and unappropriated flows. Simulated regulated flows represent physical flows that would occur if a specified scenario of water resources development and use was to be combined with historical natural river system hydrology.

Wurbs, Ralph A., and Ming-Yue Yang. 2022. "Statistical Assessments of River Flow Alterations and Environmental Flow Standards." Journal of Water Management Modeling 30: C481. https://doi.org/10.14796/JWMM.C481

(c) Wurbs and Yang 2022. www.chijournal.org ISSN 2292-6062. 
Unappropriated flows are portions of regulated flows that are available for appropriation by additional water use demands. The unappropriated flow at a site in a day of the simulation may be less than the regulated flow due to requirements for instream flow needs at that or downstream locations or senior downstream diversion or storage rights.

\section{Modeling and analysis tools integrated in the research}

The simulation and data management systems and statistical analysis methods combined in the research reported in this paper were implemented using public domain software, available free-of-charge with detailed documentation at websites of the sponsoring agencies listed in Table 1.

Table 1 Databases and modeling software.

\begin{tabular}{|c|c|c|}
\hline & Database or Modeling System & Responsible Agency \\
\hline NWIS & National Water Information System & $\begin{array}{l}\text { United States Geological Survey (USGS), } \\
\text { https://waterdata.usgs.gov/nwis }\end{array}$ \\
\hline WAM & Water Availability Modeling System & $\begin{array}{l}\text { Texas Commission on Environmental Quality } \\
\text { (TCEQ), https://www.tceq.texas.gov/permitting/ } \\
\text { water rights/wr technical-resources/wam.html }\end{array}$ \\
\hline WRAP & Water Rights Analysis Package & $\begin{array}{l}\text { Texas A\&M University, } \\
\text { https://wrap.engr.tamu.edu/ }\end{array}$ \\
\hline DSS & Data Storage System & $\begin{array}{l}\text { Hydrologic Engineering Center, https://www.hec. } \\
\text { usace.army.mil/software/hec-dss/ }\end{array}$ \\
\hline IHA & Indicators of Hydrologic Alteration & $\begin{array}{l}\text { Nature Conservancy, https://www.conservation- } \\
\text { gateway.org/ConservationPractices/Freshwater/ } \\
\text { EnvironmentalFlows/MethodsandTools/ } \\
\text { IndicatorsofHydrologicAlteration/Pages/indica- } \\
\text { tors-hydrologic-alt.aspx. }\end{array}$ \\
\hline
\end{tabular}

\subsection{United States Geological Survey National Water Information System}

Daily flow records at USGS gauges were downloaded for this research from the NWIS website maintained by the USGS. The many water quantity and quality parameters in the NWIS database include daily flows at 28288 gauges, which include 1044 gauges in Texas. The Trinity River basin has 39 USGS gauges with daily flow records of $>25 y$, with the longest record extending from 1903 to the present.

\subsection{Texas water availability modeling system}

The statewide WAM system maintained by the Texas Commission on Environmental Quality (TCEQ) consists of the generalized Water Rights Analysis Package (WRAP) developed at Texas A\&M University (TAMU), which can be applied anyplace in the world, and WRAP simulation input datasets for the river basins of Texas (Wurbs 2005; 2015). The generalized WRAP combined with a dataset from the TCEQ WAM system or modification thereof is called a water availability model (WAM).

Wurbs (2011) reviews the literature of modeling reservoir and river system management and compares WRAP with other modeling systems. WRAP based assessments of water availability and supply reliability are performed in three stages: (1) compilation of water management and hydrology datasets; (2) simulation of specified water resources development, management, and use scenarios during assumed repetitions of historical natural hydrology; and (3) organizing simulation results and computing frequency and reliability metrics.

The 15 major river basins and eight coastal basins of Texas are modeled as 20 WAMs. Operation of 3450 dams and reservoirs and other constructed facilities in accordance with treaties between the U.S. and Mexico, five interstate compacts, 6200 water rights permits, federal water supply contracts, and other institutional arrangements is simulated (Wurbs 2005; 2015; 2021a). The TCEQ WAM website includes WRAP input datasets for all Texas river basins, environmental flow standards with supporting information describing their development, and an array of other information.

The TCEQ WAM and TAMU WRAP websites are linked. The WRAP software and manuals, other related publications, various datasets, and training courses can be downloaded from the WRAP website. The WRAP-WAM system routinely applied in planning and water allocation is based on a monthly computational time step (Wurbs 2019a, b; 2021a, b) but recently has been expanded to in-clude daily modeling capabilities and other features required for simulating environmental flow standards (Wurbs and Hoffpauir 2021).

Authorized and current use scenario datasets available at the TCEQ WAM website reflect existing constructed facilities. The authorized use scenario assumes all water rights permit holders use the full amount of water to which they are legally entitled, subject to water availability. Many water rights permits include projected future water needs. The current use scenario simulates recent actual water use. Texas Water Development Board (2017) WAM datasets used in planning studies reflect projections of future water needs. Model users modify the WAM datasets to reflect water needs, proposed projects and management strategies of interest.

The monthly WRAP-WAM system has been applied for many years by water right permit applicants or their consultants and TCEQ staff in administration of the water rights system. TWDB staff, regional planning groups, river authorities, and consulting engineering firms apply the modeling system in regional, statewide, and operational planning studies. The modeling system has also been applied in university and agency research studies to explore a variety of water management issues (Wurbs 2021a).

\subsection{New daily WRAP modeling system}

The version of WRAP routinely used with Texas WAM datasets is based on a monthly computational time step. The May 2019 and January 2021 WRAP software and manuals expand the monthly modeling system to include daily modeling capabilities with monthly-to-daily naturalized flow disaggregation, flow routing, forecasting, flood control reservoir operations, and instream flow standards with subsistence, base, and high pulse flow 
components (Wurbs and Hoffpauir 2021). The U.S. Army Corps of Engineers (USACE) Hydrologic Engineering Center (HEC) Data Storage System (DSS) has been fully integrated in the latest WRAP programs. A driving motivation for the daily modeling system is a legislatively mandated requirement that environmental flow standards be established and incorporated in the TCEQ WAM system (Wurbs 2015; 2017).

Pauls and Wurbs (2016) applied new developmental daily modeling features of WRAP to model environmental flow requirements in the Colorado River basin. Wurbs (2019c, d; 2020) incorporated SB3 environmental flow standards in daily versions of the Brazos, Trinity, and Neches WAMs to compute daily instream flow targets that were summed to monthly targets for incorporation in the WRAP input dataset for the monthly models. Naturalized and simulated regulated flows from the daily version of the Trinity WAM are compiled and analyzed in the study reported in this paper.

\subsection{Hydrologic Engineering Center - Data Storage System}

The HEC of the U.S. Army Corps of Engineers (USACE) developed and maintains several generalized modeling systems that are extensively used by government agencies, engineering firms, and universities throughout the United States and abroad. HEC-DSS and its HEC-DSSVue (HEC-DSS Visual Utility Engine) interface are shared by HEC models and have also been incorporated in other non-HEC modeling systems, including WRAP and Indicators of Hydrologic Alteration (IHA), described below, to manage time series data. WRAP programs read and create DSS files. HEC-DSSVue is an integral component of WRAP. The Nature Conservancy's IHA software also reads and creates DSS files of time series data.

HEC-DSSVue (Hydrologic Engineering Center 2009) includes features for performing statistical analyses. The HEC-SSP Statistical Software Package (Hydrologic Engineering Center 2016) provides more sophisticated statistical analysis options that are particularly useful for flood studies. Both HEC-DSSVue and HEC-SSP include options for downloading time series data from the USGS NWIS website directly into DSS files.

\subsection{The Nature Conservancy indicators of hydro- logic alteration}

Statistical trend analyses of flows of the Trinity River are performed in this study with the IHA software developed by the Nature Conservancy. The IHA software package quantifies flow alterations based on ecologically meaningful statistics of historical observed daily streamflows (Richter et al. 1996; Richter et al. 1997; Mathews and Richter 2007; Nature Conservancy 2009). The IHA methodology was applied in this study with an optional software product called $\mathrm{R}$ that provides auxiliary routines for data manipulation, mathematical operations, and graphical displays $(R$ Development Core Team 2019).
Many researchers have employed IHA methods to investigate alterations to flows in river systems in various countries (Gao et al. 2009; Lin et al. 2014; Peres and Cancelliere 2016; Cheng et al. 2018; Pal et al. 2019). Yang (2016) applied the IHA in research studies of the Brazos and Trinity River basins of Texas. This paper presents IHA statistical analyses of observed flows of the Trinity River recorded at four gauges and simulated daily flows derived from the Trinity WAM simulation model.

\section{Environmental flow standards in Texas}

The population of Texas increased from 3060000 people in 1900 to 9620000 in 1960, 20950000 in 2000, 25250000 in 2010, and 29700000 in 2020 and is projected by the Texas Water Development Board (2017) to increase to 42300000 in 2050. The state has 188 major dams or reservoirs with water supply storage capacities ranging from $6.4 \times 10^{6} \mathrm{~m}^{3}$ to $5.5 \times 10^{9} \mathrm{~m}^{3}$ and thousands of reservoirs smaller than $6.4 \times 10^{6} \mathrm{~m}^{3}$. Hydroelectric plants are located at many of the dams. Thirty-eight multipurpose reservoirs have large flood control pools in addition to water supply storage, and many other dams have been constructed solely for flood control. Most of the dams were constructed since 1940. Over half of statewide water needs are currently supplied from the reservoirs, with the remainder from groundwater. Severe aquifer depletions are forcing a growing reliance on surface water supply.

Protecting instream flows in the river systems of Texas (Figure 1) has been a concern for many years. Efforts in establishing environmental flow standards (EFS) have greatly intensified since the Texas Legislature in 2001 authorized the Texas Instream Flow Program (TIFP) to advance scientific knowledge and improve water management practices (National Research Council 2005; Wurbs $2015,2017)$. The scientific and water management communities recognized that decades would be required to fully accomplish the goals of the TIFP. A process was created by 2007 legislation, Senate Bill 3 (SB3), to expedite the establishment of EFS for priority river reaches based on best currently available information and expert opinion. The SB3 process anticipates future improvements to the flow standards as additional scientific knowledge and water management capabilities are developed.

EFS have been established through the SB3 process for priority reaches of the river systems that flow from Texas directly into the Gulf of Mexico. The EFS are adopted by the TCEQ based on recommendations of science teams and stakeholder committees for each individual river system. An array of information regarding the officially established EFS and the SB3 process can be accessed through the TCEQ website listed in Table 1. The flow standards are presently being incorporated in the TCEQ WAM system for use in both planning studies and administration of water right permits. Applications for new water rights permits or modifications to existing permits will be subject to the EFS. Existing water right permit holders are not subject to the SB3 EFS unless their permits are amended after establishment of the SB3 EFS.

Environmental flow needs are defined in terms of the magnitude, frequency, timing, duration, and spatial distribution of the 
flows required to sustain freshwater and estuarine ecosystems throughout major river, tributary stream, and estuary systems. Environmental flow requirements were initially prescribed in Texas and elsewhere primarily as minimum low flow limits. However, in Texas, like elsewhere, the importance of considering all elements of a flow regime is now well recognized. EFS established through the SB3 process and incorporated into the WAM system are defined based on seasonally varying flow regimes with subsistence flows, base flows, inbank high flow pulses, and overbank flooding events.

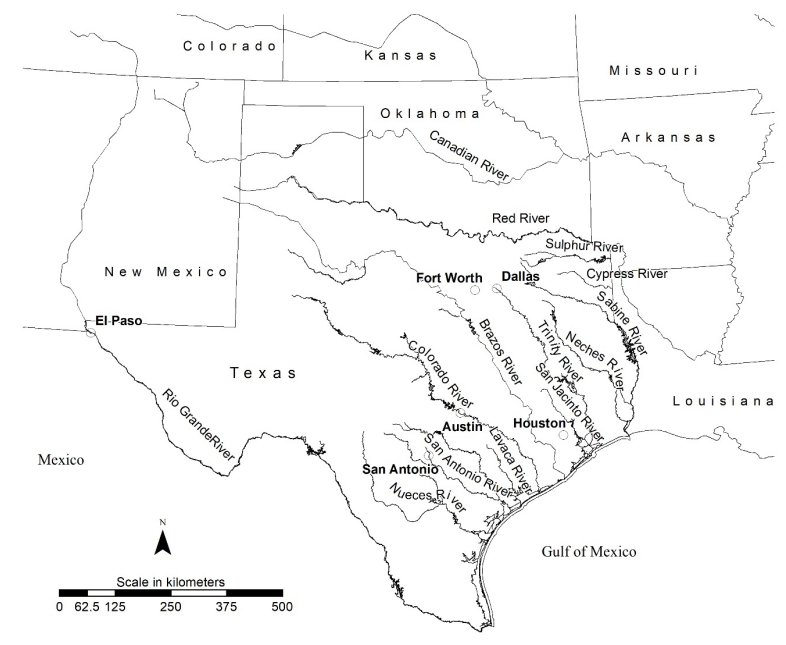

Figure 1 Major rivers and largest cities of Texas.

The National Research Council (2005) of the American National Academy of Sciences evaluated the general framework and procedures developed by the TIFP and adopted in the SB3 process for establishing environmental flow standards. Wurbs and Hoffpauir (2013) and Opdyke et al. (2014) review available modeling and analysis methods for establishing and implementing the SB3 streamflow requirements. Opdyke et al. (2014) describe the hydrologic analysis methods adopted by the science teams in establishing the SB3 environmental flow standards based on computing relevant summary frequency statistics for historical observed daily streamflows for defined flow regime components using Microsoft Excel spreadsheets.

\section{Trinity River basin}

The Trinity River basin (Figures 1 and 2) extends from just south of the Oklahoma-Texas border southeastward for about $640 \mathrm{~km}$ to the Galveston Bay and estuary system, which is one of the most productive ecosystems and commercial fisheries in the U.S. The basin encompasses an area of $46600 \mathrm{~km}^{2}$ that transitions from western rolling plains, through central Texas prairies and East Texas piney woods, into the gulf coastal prairies. Average annual rainfall increases from west to east across the basin from $737 \mathrm{~mm}$ to $1350 \mathrm{~mm}$. Average annual temperature increases from north to south across the basin from $17^{\circ} \mathrm{C}$ to $21^{\circ} \mathrm{C}$. According to Dewitz (2019), the land cover of Trinity River basin consists of $25 \%$ herbaceous, $23 \%$ hay or pasture, $18 \%$ forest, $14 \%$ developed land, $7 \%$ wetlands, $6 \%$ crops, $4 \%$ open water, $2 \%$ shrub or scrub, and $<1 \%$ barren land. Major tributaries in the basin include the West Fork of the Trinity River, Elm Fork of the Trinity River, East Fork of the Trinity River, Cedar Creek, Chambers Creek and Richland Creek.

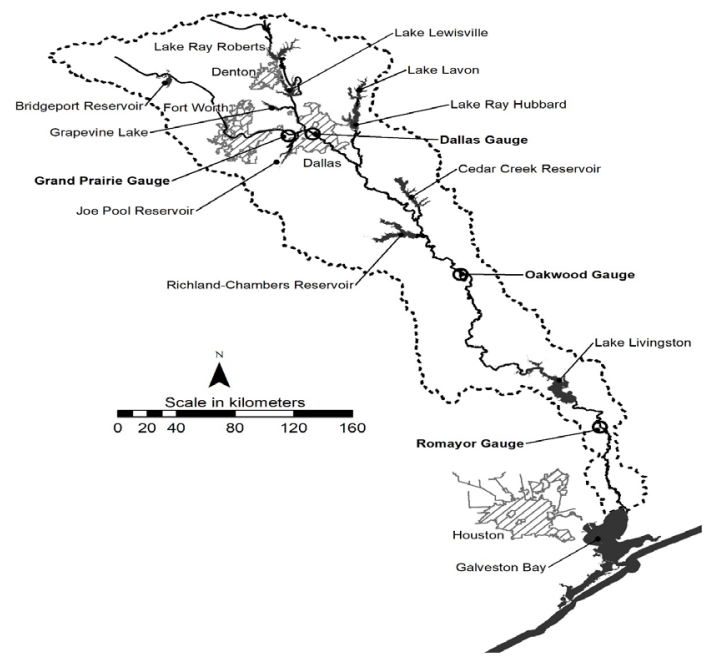

Figure 2 Trinity River basin.

\subsection{Water resources development}

The Dallas-Fort Worth (DFW) metropolitan area in the upper Trinity River basin, with a 2019 population of 6800 000, has been one of the fastest growing large metro areas in the U.S. over the past several decades. The cities of Dallas and Fort Worth had populations of 1350000 and 550000 in 2019, respectively. Seventy other cities in the DFW metro area have populations >10 000 . Many large dams were constructed on the Trinity River and its tributaries during 1930-1990 to provide water supply and flood protection for the growing population.

Groundwater supplies are limited in the upper Trinity River basin. Most water needs are supplied from reservoirs on the Trinity River and tributaries. The major regional water suppliers are Dallas Water Utilities, North Texas Municipal Water District, Tarrant Regional Water District, and Trinity River Authority. Significant local water providers include the cities of Denton, Grapevine and Weatherford, and Dallas County Park Cities Municipal Utilities District. The city of Houston, another large continually growing metropolitan area, located in the adjoining San Jacinto River basin, transports water by pipeline from Lake Livingston on the lower Trinity River (Figure 2). Water is also transported by pipeline from the upper Neches and Sabine Rivers to supply water to users in the upper Trinity River basin.

The 15 largest reservoirs in the basin are listed in Table 2. The years during which construction was completed and impoundment of water initiated are shown in the third column. Water supply and flood control storage capacities are tabulated 
in the last two columns. The ten largest reservoirs are included in the basin map of Figure 2.

Table 2 Largest reservoirs in the Trinity River basin.

\begin{tabular}{|c|c|c|c|c|}
\hline \multirow{2}{*}{ Reservoir } & \multirow{2}{*}{ Stream } & \multirow{2}{*}{$\begin{array}{l}\text { Initial Impound- } \\
\text { ment }\end{array}$} & \multicolumn{2}{|c|}{ Storage capacity $\left(10^{6} \mathrm{~m}^{3}\right)$} \\
\hline & & & Water Supply & Flood Control \\
\hline Livingston & Trinity River & 1969 & 2160 & - \\
\hline Richland-Chambers & Richland Creek & 1987 & 1400 & - \\
\hline Ray Roberts & Elm Fork Trinity & 1987 & 986 & 322 \\
\hline Cedar Creek & Cedar Creek & 1965 & 838 & - \\
\hline Lewisville & Elm Fork Trinity & 1954 & 763 & 648 \\
\hline Ray Hubbard & East Fork Trinity & 1968 & 604 & - \\
\hline Lavon & East Fork Trinity & 1953 & 563 & 340 \\
\hline Bridgeport & West Fork Trinity & 1932 & 477 & - \\
\hline Eagle Mountain & West Fork Trinity & 1934 & 259 & - \\
\hline Joe Pool & Mountain Creek & 1986 & 218 & 157 \\
\hline Grapevine & Denton Creek & 1952 & 200 & 294 \\
\hline Benbrook & Clear Fork Trinity & 1952 & 109 & 210 \\
\hline Navarro Mills & Richland Creek & 1963 & 78.1 & 177 \\
\hline Bardwell & Waxahachie Creek & 1965 & 67.7 & 98.2 \\
\hline Fairfield & Big Brown Creek & 1969 & 62.4 & - \\
\hline
\end{tabular}

The USACE owns eight multipurpose reservoirs that include flood control pool storage capacities, listed in the last column of Table 2. These reservoirs are operated by the USACE for flood control, and nonfederal sponsors hold contracts for their water supply storage capacity. The City of Houston and Trinity River Authority jointly own and operate Lake Livingston. The other reservoirs are owned by various municipal water supply entities and electric power companies that use the water for thermal electric power plant cooling. Many other smaller towns, industries, and farmers scattered throughout the basin own smaller reservoirs and divert water from the Trinity River and its tributaries. Recreation is popular at most of the lakes in the basin.

\subsection{Senate Bill 3 environmental flow standards}

The Texas Commission on Environmental Quality (2011) established EFS for the Trinity and San Jacinto Rivers and Galveston Bay effective May 2011 based on recommendations of science and stakeholder committees and public review. A work plan for continuing periodic review and improvement of the EFS has also been developed. Instream flow standards were established at four sites in the Trinity River basin and two sites in the San Jacinto River basin. Frequency statistics for daily flows recorded at USGS gauging stations at the six sites were used with other available information to create the EFS based largely on the expert judgement of the assembled scientists and water managers (Opdyke et al. 2014).

SB3 EFS for the Trinity River basin are specified for the sites of the four USGS gauging stations listed in Table 3 with locations shown in Figure 2. The standards incorporate the metrics tabulated in Tables 4 and 5. The flow standards include seasonal subsistence flows, base flows, and high flow pulses. Seasons are defined as Winter (December, January, February), Spring (March, April,
May), Summer (June, July, August), and Fall (September, October, November). June through November is treated as a single season in tracking high flow pulses.

If the flow at the gauge is less than the subsistence flow limit in Table 4, water rights holders may not divert water or refill storage anyplace that would lower the flow at the gauge site. If the flow exceeds the subsistence flow limit but is less than the base flow, upstream streamflow depletions are allowed as long as the flow does not drop below the subsistence limit at the gauge site. If the flow is greater than the base flow limit but less than the pulse flow trigger level, water rights holders may make diversions or refill reservoir storage as long as the flow is above the base flow limit. The high flow pulse standards are engaged when flow at a gauge exceeds the trigger level. Actions that affect flows at the gauge site are not allowed until either the applicable volume or duration time has passed since engagement of the trigger flow level. Two pulses per season are specified for each of the four sites.

Table 3 Gauge sites of Senate Bill 3 environmental flow standards.

\begin{tabular}{llccc}
\hline \multicolumn{1}{c}{ River } & Nearest City & Watershed Area $\left(\mathrm{km}^{2}\right)$ & USGS Gauge Period-of-Record & Mean Flow $\left(\mathrm{m}^{3} / \mathrm{s}\right)$ \\
\hline West Fork & Grand Prairie & 7940 & April 1925 to present & 20.33 \\
Trinity & Dallas & 15800 & October 1903 to present & 51.45 \\
Trinity & Oakwood & 33200 & October 1923 to present & 155.2 \\
Trinity & Romayor & 44500 & May 1924 to present & 229.8 \\
\hline
\end{tabular}

Table 4 Subsistence and base flow limits for environmental flow standards.

\begin{tabular}{lcccccccc}
\hline Gauge Site & \multicolumn{3}{c}{ Subsistence Flow Limits $\left(\mathrm{m}^{3} / \mathrm{s}\right)$} & \multicolumn{3}{c}{ Baseflow Limits $\left(\mathrm{m}^{3} / \mathrm{s}\right)$} \\
Nearest City & Winter & Spring & Summer & Fall & Winter & Spring & Summer & Fall \\
\hline Grand Prairie & 0.538 & 0.708 & 0.651 & 0.595 & 1.27 & 1.27 & 0.991 & 0.991 \\
Dallas & 0.736 & 1.05 & 0.623 & 0.425 & 1.42 & 1.98 & 1.13 & 1.42 \\
Oakwood & 3.40 & 4.53 & 2.12 & 2.83 & 9.63 & 12.7 & 7.08 & 7.36 \\
Romayor & 14.0 & 19.8 & 5.66 & 6.51 & 24.8 & 32.6 & 16.3 & 17.7 \\
\hline
\end{tabular}

Table 5 Metrics for high flow pulse components of environmental flow standards.

\begin{tabular}{llccc}
\hline \multicolumn{1}{c}{ Site } & \multicolumn{1}{c}{ Criteria } & Winter & Spring & Summer/Fall \\
\hline West Fork of Trinity & Trigger $\left(\mathrm{m}^{3} / \mathrm{s}\right)$ & 8.50 & 34.0 & 8.50 \\
River at Grand & Volume $\left(10^{6} \mathrm{~m}^{3}\right)$ & 4.32 & 9.87 & 2.22 \\
Prairie & Duration $(\mathrm{d})$ & 4 & 8 & 3 \\
& Trigger $\left(\mathrm{m}^{3} / \mathrm{s}\right)$ & 19.8 & 113 & 28.3 \\
Trinity River at & Volume $\left(10^{6} \mathrm{~m}^{3}\right)$ & 4.32 & 49.3 & 10.5 \\
Dallas & Duration $(\mathrm{d})$ & 3 & 9 & 5 \\
& Trigger $\left(\mathrm{m}^{3} / \mathrm{s}\right)$ & 85.0 & 198 & 70.8 \\
Trinity River at & Volume $\left(10^{6} \mathrm{~m}^{3}\right)$ & 22.2 & 160 & 28.4 \\
Oakwood & Duration $(\mathrm{d})$ & 5 & 11 & 5 \\
& Trigger $\left(\mathrm{m}^{3} / \mathrm{s}\right)$ & 227 & 283 & 113 \\
Trinity River at & Volume $\left(10^{6} \mathrm{~m}^{3}\right)$ & 98.7 & 185 & 74.0 \\
Romayor & Duration $(\mathrm{d})$ & 7 & 9 & 5 \\
& & & & 5 \\
\hline
\end{tabular}




\section{Indicators of hydrologic alteration analy- ses of observed flows}

River regulation and water resources development and use affect the flows of the Trinity River in various ways. Storage attenuation effects of reservoir flood control operations that may be pronounced in a daily or hourly flow hydrograph are dissipated in a hydrograph of mean monthly flow rates. Variability is reduced by averaging over a larger time interval. Streamflow attenuation and depletion effects may be great immediately below a dam but diminish downstream with unregulated inflows. Low flows of the Trinity River are significantly increased by return flows through municipal wastewater treatment plants from water use supplied from streamflow stored in reservoirs and groundwater. Reservoir storage for both flood control and water supply decreases high flows.

Continuous flows observed at gauging stations are recorded as time series of daily means. Period-of-record observed daily flows at the four gauge sites in Table 3 are plotted in Figures $3,4,5$ and 6 . Flows of the Trinity River, like all rivers in Texas, are extremely variable with continuous, storm event, seasonal, and multiple year fluctuations reflecting the extremes of droughts and floods as well as more frequent but less severe variations. Detecting long term alterations in river flows is difficult due to the great continuous natural flow variability. The IHA methodology was applied in the study reported in this paper to quantify permanent long-term alterations to river flow characteristics.

The IHA statistical analysis package includes options to select from 33 possible hydrologic parameters to quantify changes in flow characteristics (Mathews and Richter 2007; Nature Conservancy 2009). The IHA methodology is based on two primary considerations: (1) the ecological relevance of parameters and (2) abilities to reflect human induced alterations in flow regimes. The ecological relevance of hydrologic parameters is outlined by Mathews and Richter (2007) and the Nature Conservancy (2009). The parameters that may be computed with the IHA software are organized in the following five groups.

1. Magnitude of monthly flow conditions (mean or median daily for each of the 12 months).

2. Magnitude and duration of annual extreme flow conditions (annual minima or maxima of $1 d, 3 d, 7 d$, $30 \mathrm{~d}$ or $90 \mathrm{~d}$ duration mean flows; number of zero flow days).

3. Timing of annual extreme water conditions (date of annual minimum or maximum daily flow in each year).

4. Frequency and duration of high and low flow pulses (number of low or high pulses in each year; mean or median of low or high pulses in each year).

5. Rate and frequency of change (mean or median of all positive or negative differences between consecutive daily flows; number of reversals between rising and falling flows).

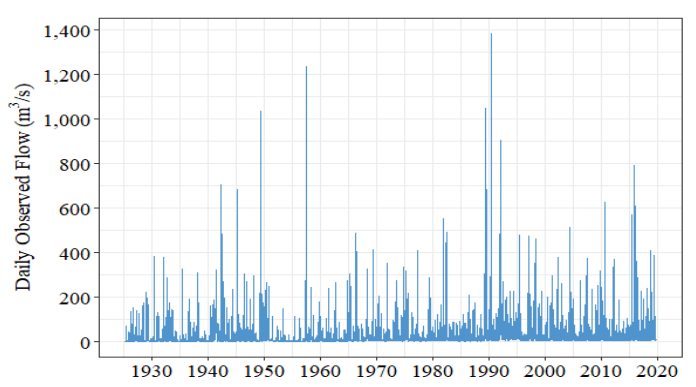

Figure 3 Observed daily flow at gauge on the West Fork of the Trinity River at Grand Prairie from April 1925 through August 2019.

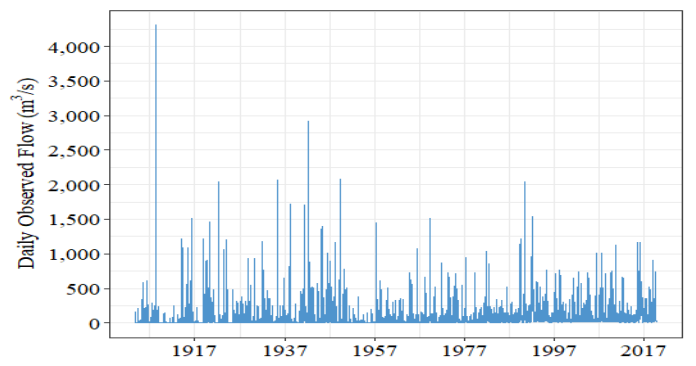

Figure 4 Observed daily flow at the gauge on the Trinity River at Dallas from October 1903 through August 2019.

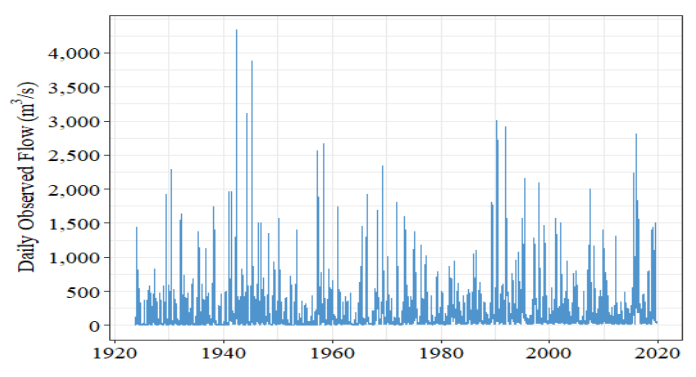

Figure 5 Observed daily flow at the gauge on the Trinity River at Oakwood from October 1923 through August 2019.

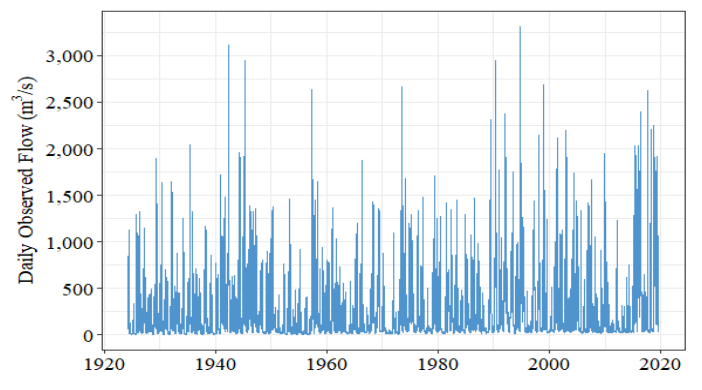

Figure 6 Observed daily flow at the gauge on the Trinity River at Romayor from May 1924 through August 2019. 
Since regulation of rivers with reservoirs and water resources development and use are known to cause alterations of the high and low flows, four hydrologic parameters, namely minima and maxima of $7 \mathrm{~d}$ duration mean flows from group 2, and number of low and high flow pulses in each year from group 4, were selected to statistically analyze these changes in the Trinity River.

The annual $7 \mathrm{~d}$ minimum and maximum flows from the group 2 metrics and the numbers of low flow and high flow pulses each year from group 4 are presented in Figures 7, 8, 9 and 10 to illustrate the analyses of long-term alterations to the observed flows at the four sites listed in Table 3.

The minimum mean flows for any seven consecutive days of each year of the period-of-record at the four gauges are plotted in Figure 7. The corresponding annual maxima of $7 \mathrm{~d}$ mean flows are plotted in Figure 8. The trend lines in Figures 7 and 8 are generated by the IHA least squares linear regression feature. According to the slopes of the regression lines and the $p$-values of the slopes, at $95 \%$ significance level, annual minima of $7 \mathrm{~d}$ mean flows have significantly increased at the four gauges as a result of increases in return flows from municipal and industrial wastewater treatment plants. However, at a 95\% significance level, alterations in maximum annual $7 \mathrm{~d}$ high flows are not statistically significant at any of the four sites.
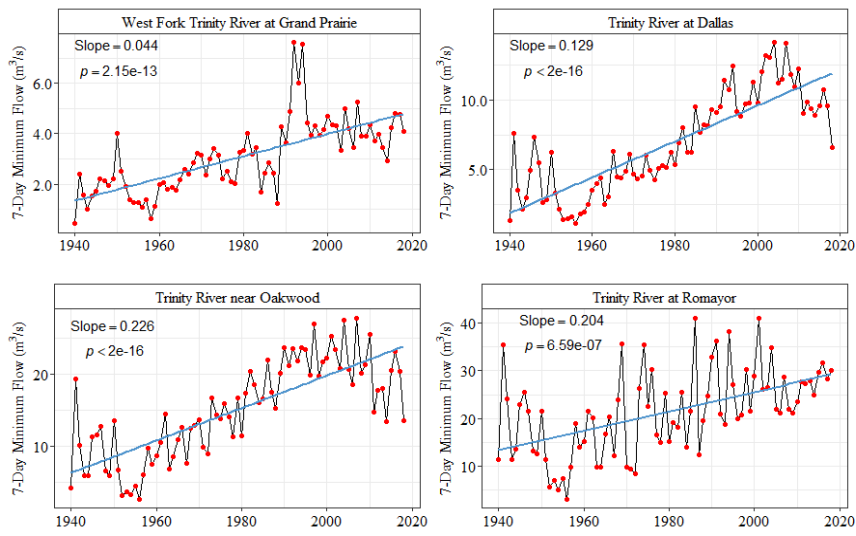

Figure 7 IHA $7 \mathrm{~d}$ minimum observed flow at four gauges.
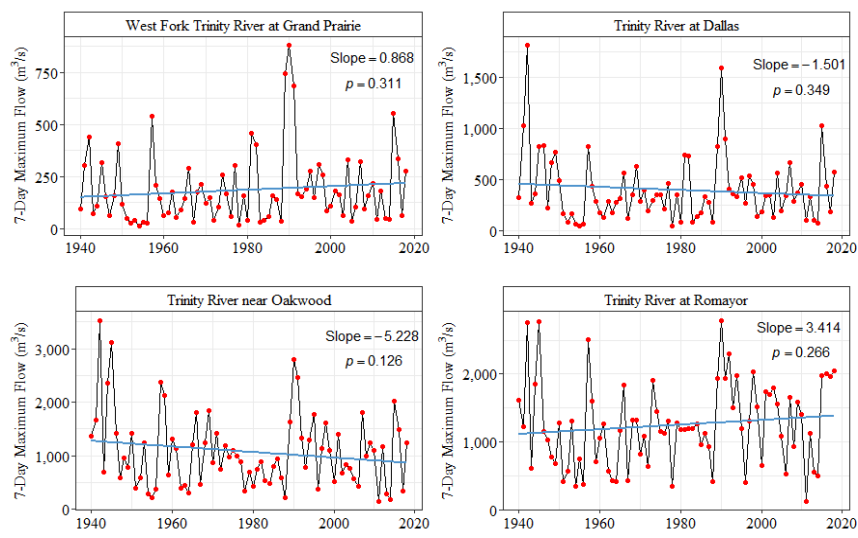

Figure 8 IHA $7 \mathrm{~d}$ maximum observed flow at four gauges.
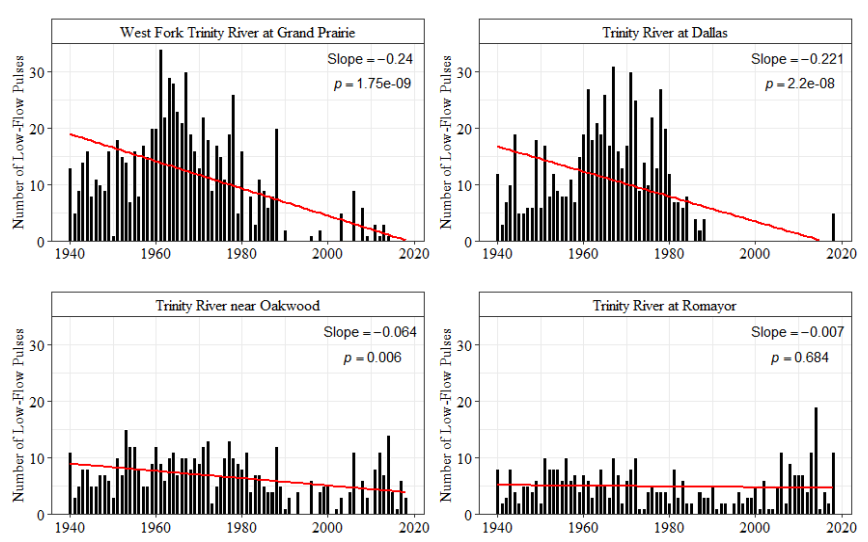

Figure 9 Number of low flow pulses for observed flows.
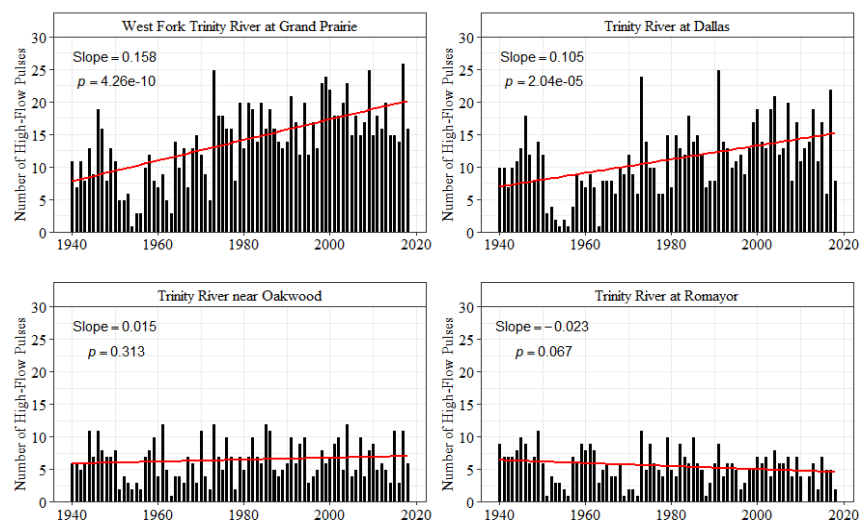

Figure 10 Number of high flow pulses for observed flows.

Figures 9 and 10 show the number of IHA-defined low and high flow pulses that occurred each year at the four sites. A low pulse is defined as one standard deviation smaller than the mean flow rate, and a high pulse is one standard deviation above the mean flow rate. Trend lines are generated using linear regression. At a 95\% significance level, the gauges at Grand Prairie, Dallas, and Oakwood have experienced noticeably decreasing numbers of low flow pulses. It is worth pointing out that no low pulses were observed at the Dallas gauge site between 1989 and 2017, which may be a result of the impoundment of the Ray Roberts reservoir. Low flow pulse occurrence appears to be fairly stationary at the Romayor gauge. At 95\% significance level, the number of high flow pulses at the Grand Prairie and Dallas gauges increased significantly over time, while the number of high flow pulses at the Romayor and Oakwood sites remained relatively constant.

\section{Comparison of naturalized and observed river flows}

Observed flows at a gauge site represent actual historical conditions of river basin development that have typically changed over time. Naturalized flows are developed within the WRAP-WAM sys- 
tem by adjusting observed monthly flows to remove the effects of historical water resources development and use (Wurbs 2006). Naturalized flows are disaggregated from monthly to daily in a daily simulation in proportion to input daily flow pattern hydrographs while maintaining the monthly naturalized flow volumes (Wurbs and Hoffpauir 2021).

WAM naturalized flows represent river flows unaltered by river regulation and water resources development and use. WAM simulated regulated flows represent altered flows but reflect the same altered condition throughout the entire hydrologic period-of-analysis simulation. Naturalized and simulated regulated flows should conceptually be stationary or have homogeneous characteristics over time. There should be no permanent longterm trends or changes. However, the flow adjustment procedures for computing naturalized monthly flows are necessarily approximate and incomplete. Flows may be altered by other factors not included in the adjustments. Disaggregation of monthly naturalized flows to daily flows is also approximate. Plots, trend analyses, and other statistical analyses of naturalized flows performed with IHA and WRAP are employed to test stationarity or the extent to which the flow naturalization process removed human induced alterations to the river flows.

The Trinity WAM has a hydrologic period-of-analysis of 28855 days extending from January 1, 1940 through December 31,2018 . The plot of the 28855 daily mean flows at the gauge site on the Trinity River near Romayor in Figure 11 illustrates the tremendous temporal variability of streamflow throughout Texas. The metrics in Tables 6 and 7 are used to compare naturalized and observed flows.

Table 6 Frequency statistics for 1940-2018 daily observed and naturalized flows.

\begin{tabular}{lcccccccc}
\hline Gauge Site & \multicolumn{2}{c}{$\begin{array}{c}\text { Grand Prairie } \\
\text { Flow Type }\end{array}$} & \multicolumn{2}{c}{ Dallas } & \multicolumn{2}{c}{ Oakwood } & \multicolumn{2}{c}{ Romayor } \\
Observed & $\begin{array}{c}\text { Natural- } \\
\text { ized }\end{array}$ & Observed & $\begin{array}{c}\text { Natural- } \\
\text { ized }\end{array}$ & Observed & $\begin{array}{c}\text { Natural- } \\
\text { ized }\end{array}$ & Observed & $\begin{array}{c}\text { Natural- } \\
\text { ized }\end{array}$ \\
\hline Flow Unit & $\left(\mathrm{m}^{3} / \mathrm{s}\right)$ & $\left(\mathrm{m}^{3} / \mathrm{s}\right)$ & $\left(\mathrm{m}^{3} / \mathrm{s}\right)$ & $\left(\mathrm{m}^{3} / \mathrm{s}\right)$ & $\left(\mathrm{m}^{3} / \mathrm{s}\right)$ & $\left(\mathrm{m}^{3} / \mathrm{s}\right)$ & $\left(\mathrm{m}^{3} / \mathrm{s}\right)$ & $\left(\mathrm{m}^{3} / \mathrm{s}\right)$ \\
Mean & 21.5 & 24.2 & 56.8 & 68.6 & 159 & 178 & 235 & 258 \\
Std Dev & 52.5 & 75.6 & 114 & 208 & 271 & 355 & 347 & 399 \\
Minimum & 0.340 & 0.00 & 0.283 & 0.00 & 2.41 & 0.00 & 2.95 & 0.00 \\
$99 \%$ & 1.10 & 0.00 & 1.64 & 0.00 & 4.36 & 0.00 & 7.48 & 0.00 \\
$98 \%$ & 1.36 & 0.00 & 1.93 & 0.00 & 5.55 & 0.00 & 9.88 & 1.51 \\
$95 \%$ & 1.70 & 0.00 & 2.83 & 0.00 & 9.03 & 1.19 & 15.0 & 6.37 \\
$90 \%$ & 2.32 & 0.19 & 4.56 & 1.15 & 13.6 & 5.62 & 21.9 & 13.6 \\
$70 \%$ & 4.25 & 2.80 & 9.60 & 7.06 & 25.7 & 25.1 & 40.4 & 47.8 \\
$50 \%$ & 6.20 & 5.80 & 14.2 & 14.9 & 45.9 & 55.2 & 77.6 & 160 \\
$30 \%$ & 11.0 & 12.5 & 33.4 & 33.8 & 131 & 135 & 212 & 250 \\
$10 \%$ & 50.7 & 50.7 & 164 & 147 & 453 & 453 & 674 & 676 \\
Maximum & 1380 & 1920 & 2920 & 4520 & 4333 & 7220 & 3310 & 5800 \\
\hline
\end{tabular}

The mean, standard deviation and flow rates exceeded during specified percentages of the 28855 d in 1940-2018 are tabulated in Table 6 for the daily observed and naturalized flows at the four gauge sites listed in Table 3. The linear regression trend slopes compared in Table 7 represent long term average changes in flow rates during the 79 y $1940-2018$ in units of $\mathrm{m}^{3} / \mathrm{s} / \mathrm{y}$. The flow naturalization process consists of adjusting observed flows to remove permanent long term alterations, which drives the regression trend slopes for the naturalized flows toward zero. According to the $95 \%$ confidence interval of the two sample $t$-tests, there are no significant differences between the trend slopes of observed and naturalized annual series at the four gauges.

Table 7 Linear regression trend slopes in $\mathrm{m}^{3} / \mathrm{s} / \mathrm{y}$ for 1940 2018 annual series.

\begin{tabular}{lcccc}
\hline \multicolumn{1}{c}{ Gauge Site } & Grand Prairie & Dallas & Oakwood & Romayor \\
\hline $\begin{array}{l}\text { 1940-2018 Observed Flow Rates } \\
\text { Slope of annual mean flow rates }\end{array}$ & 0.166 & 0.423 & 0.668 & 0.787 \\
Slope of annual median daily flows & 0.047 & 0.369 & 0.640 & 0.486 \\
Slope of 7 d minimum flows & 0.044 & 0.129 & 0.226 & 0.204 \\
Slope of 7 d maximum flows & 0.868 & -1.501 & -5.228 & 3.414 \\
\hline \multicolumn{1}{c}{ Naturalized Flow Rates } & & & & \\
Slope of annual mean flow rates & 0.057 & 0.252 & 0.493 & 0.606 \\
Slope of annual median daily flows & 0.039 & 0.181 & 0.568 & 0.574 \\
Slope of 7 d minimum flows & 0.002 & 0.024 & 0.096 & 0.141 \\
Slope of 7 d maximum flows & 0.844 & 1.446 & 0.953 & 6.167 \\
95\% confidence interval & $(-0.739$, & $(-0.788$, & $(-3.086$, & $(-3.649$, \\
& $0.648)$ & $2.030)$ & $5.988)$ & $4.947)$ \\
\hline
\end{tabular}

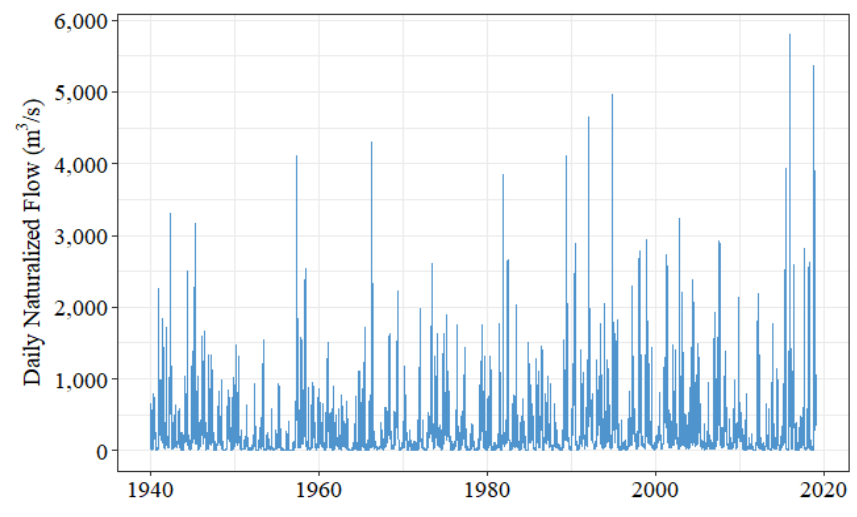

Figure 11 Daily naturalized flow of the Trinity River at Romayor.

\section{Simulation of water resources develop- ment and environmental flow stan- dards}

The term Trinity WAM refers to the generalized WRAP modeling system and a simulation input dataset for the Trinity River basin from the TCEQ WAM system or a modified version of the dataset. The TCEQ WAM datasets are designed for a monthly computational time step. A developmental daily version of the Trinity WAM (Wurbs 2019c) was employed for the study reported in this paper.

Naturalized 1940-2018 monthly streamflow at 39 gauge sites are read from the input dataset and distributed to over 
1300 ungauged sites within the simulation based on watershed parameters. Monthly naturalized flows at the $>1300$ sites are disaggregated to daily flows based on pattern hydrographs at 49 sites compiled by combining gauged flows and unregulated flows from a USACE modeling system. Naturalized flows are disaggregated from monthly to daily in a daily simulation in proportion to input daily flow pattern hydrographs while maintaining the monthly naturalized flow volumes (Wurbs 2019c; Wurbs and Hoffpauir 2021).

A WRAP-WAM simulation combines a specified scenario of water resources development and management with a hypothetical repetition of historical natural river system hydrology. The authorized use scenario adopted here reflects the premise that all water users attempt to use the full amounts authorized by water rights permits, constrained by water availability. This scenario includes operations of all presently existing dams and reservoirs. Water demands in this scenario are higher than actual current use because water rights permits may include projected future needs.

\subsection{Senate Bill 3 Environmental Flow Standards}

Minimum instream flow targets are computed in the simulation for the SB3 EFS based on the quantities shown in Tables 4 and 5 following the SB3 EFS rules explained earlier in the paper. Streamflow is maintained at or above the target minimum flow levels, subject to water availability under the priority-based water rights permit system. Junior water supply diversion and storage refilling rights are curtailed if and as necessary to protect the SB3 EFS instream flow targets. Although inflows are passed through reservoirs as necessary to preserve flows for senior downstream EFS or other senior rights, reservoir operations do not include lowering storage contents for this purpose.

The Texas water rights permit system and the WRAP simulation model are based on assigning relative priorities to all water use requirements. The SB3 EFS in the Trinity WAM affect only water rights with permits approved after December 2009 (Texas Commission on Environmental Quality 2011). No significant permits or amendments have been approved since 2009, due largely to limited available unappropriated flows. The numerous existing water permit holders and water users are thus not affected in the WAM by the junior priority EFS.

The following comparative evaluation refers to three simulations with the only difference being alternative SB3 EFS scenarios. In one simulation, the EFS metrics of Tables 4 and 5 are referenced to regulated flows, and the EFS are assigned priorities junior to all existing rights, which reflects the real-world situation. To assess the effects of priorities, the EFS are referenced to naturalized flows and assigned priorities higher than all existing rights in another simulation. The EFS are omitted in a third simulation. With the SB3 EFS hypothetically assigned higher priorities, all other water users curtail reservoir refilling and, water supply diversions that adversely affect one or more of the four EFS in each day of the simulation. Inflows are passed through the dams for higher priority downstream EFS, but releases are not made from previous storage.

SB3 EFS minimum instream flow limit targets at the four sites are computed as the simulation progresses sequentially through each of the $28855 \mathrm{~d}$ of the 1940-2018 hydrologic period-of-analysis. Frequency statistics for the targets are presented in Table 8 for two alternative simulations with the SB3 EFS modeled as being lower or higher priority than all other water rights. The minimum instream flow limits vary between the two simulations because the alternative EFS scenarios are referenced to and protect natural versus regulated streamflows.

Table 8 Frequency statistics for daily environmental flow standard targets.

\begin{tabular}{|c|c|c|c|c|c|c|c|c|}
\hline Gauge Site & \multicolumn{2}{|c|}{ Grand Prairie } & \multicolumn{2}{|c|}{ Dallas } & \multicolumn{2}{|c|}{ Oakwood } & \multicolumn{2}{|c|}{ Romayor } \\
\hline SB3 EFS & $\begin{array}{l}\text { Lower } \\
\text { than }\end{array}$ & $\begin{array}{c}\text { Higher } \\
\text { than }\end{array}$ & $\begin{array}{c}\text { Lower } \\
\text { than }\end{array}$ & $\begin{array}{c}\text { Higher } \\
\text { than }\end{array}$ & $\begin{array}{l}\text { Lower } \\
\text { than }\end{array}$ & $\begin{array}{c}\text { Higher } \\
\text { than }\end{array}$ & $\begin{array}{l}\text { Lower } \\
\text { than }\end{array}$ & $\begin{array}{c}\text { Higher } \\
\text { than }\end{array}$ \\
\hline Priority & existing & existing & existing & existing & existing & existing & existing & existing \\
\hline Flow Unit & $\begin{array}{l}\text { rights } \\
\left(\mathrm{m}^{3} / \mathrm{s}\right)\end{array}$ & $\begin{array}{l}\text { rights } \\
\left(\mathrm{m}^{3} / \mathrm{s}\right)\end{array}$ & $\begin{array}{l}\text { rights } \\
\left(\mathrm{m}^{3} / \mathrm{s}\right)\end{array}$ & $\begin{array}{l}\text { rights } \\
\left(\mathrm{m}^{3} / \mathrm{s}\right)\end{array}$ & $\begin{array}{l}\text { rights } \\
\left(\mathrm{m}^{3} / \mathrm{s}\right)\end{array}$ & $\begin{array}{l}\text { rights } \\
\left(\mathrm{m}^{3} / \mathrm{s}\right)\end{array}$ & $\begin{array}{l}\text { rights } \\
\left(\mathrm{m}^{3} / \mathrm{s}\right)\end{array}$ & $\begin{array}{l}\text { rights } \\
\left(\mathrm{m}^{3} / \mathrm{s}\right)\end{array}$ \\
\hline Mean & 1.36 & 1.93 & 2.68 & 3.26 & 8.40 & 8.85 & 31.0 & 33.0 \\
\hline Std Dev & 3.22 & 6.67 & 11.9 & 12.8 & 30.9 & 32.2 & 44.5 & 47.9 \\
\hline Minimum & 0.000 & 0.000 & 0.000 & 0.000 & 0.000 & 0.000 & 0.0381 & 0.000 \\
\hline $98 \%$ & 0.0436 & 0.000 & 0.0428 & 0.000 & 0.0445 & 0.000 & 0.0464 & 0.000 \\
\hline $95 \%$ & 0.0546 & 0.000 & 0.0433 & 0.000 & 0.0578 & 0.000 & 1.52 & 2.38 \\
\hline $90 \%$ & 0.0618 & 0.000 & 0.0451 & 0.000 & 0.398 & 1.13 & 7.98 & 8.80 \\
\hline $80 \%$ & 0.198 & 0.430 & 0.0521 & 0.000 & 1.13 & 1.13 & 16.3 & 16.3 \\
\hline $70 \%$ & 0.630 & 0.991 & 0.0618 & 0.000 & 1.13 & 1.42 & 16.3 & 17.7 \\
\hline $50 \%$ & 0.991 & 0.991 & 1.13 & 1.13 & 1.42 & 1.42 & 17.7 & 24.8 \\
\hline $30 \%$ & 1.27 & 1.27 & 1.42 & 1.42 & 1.42 & 1.42 & 32.6 & 32.6 \\
\hline $10 \%$ & 1.27 & 1.27 & 1.98 & 1.98 & 1.98 & 1.98 & 32.6 & 32.6 \\
\hline Maximum & 34.0 & 114 & 113 & 113 & 198 & 198 & 283 & 283 \\
\hline
\end{tabular}

The daily EFS targets for the low priority scenario at the site on the Trinity River near Romayor are plotted in Figure 12. Failures or shortages in meeting the EFS are negligible at all four sites in both simulations.

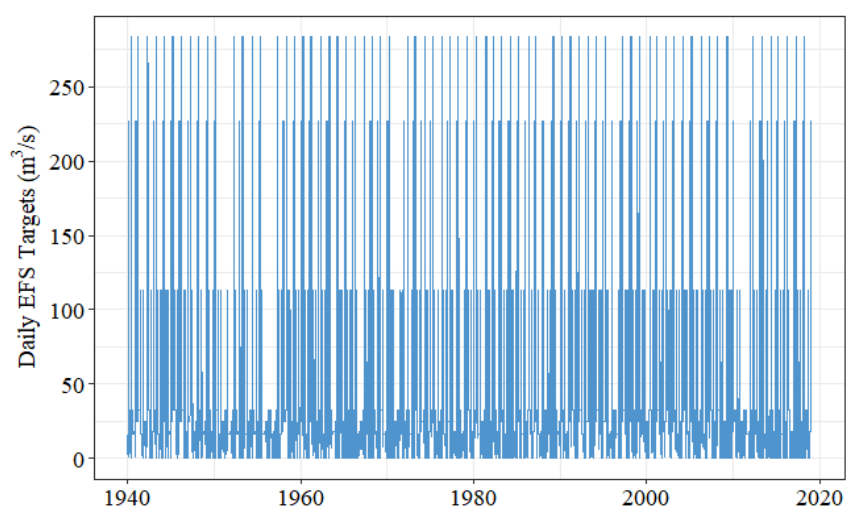

Figure 12 SB3 EFS daily minimum instream flow limits for the Trinity River at Romayor. 


\subsection{Simulated reservoir storage contents}

The 697 reservoirs modeled in the Trinity WAM have a total permitted water supply storage capacity of $9.37 \times 10^{9} \mathrm{~m}^{3}$. The 15 largest reservoirs (Table 2 ) have water supply storage capacities totaling $8.79 \times 10^{9} \mathrm{~m}^{3}$, which is $93.8 \%$ of the total of the 697 reservoirs. The eight USACE reservoirs listed in Table 2 contain all of the flood control storage capacity modeled in the daily WAM.

Reservoir storage content provides a meaningful measure of water supply capabilities. The summation of end-ofday stor-age content of the 15 largest reservoirs for each of the $28855 \mathrm{~d}$ of the 1940-2018 simulation are plotted in Figure 13 for the alterna-tive simulations with SB3 EFS having lower (or omitted) priority versus higher priority than all other water rights. With SB3 EFS assigned lower priorities, they have no effect on existing water rights permit holders and thus no effect on storage content. The two storage plots of Figure 13 demonstrate the effects of hypo-thetically protecting natural flows by making all water rights per-mit holders subject to SB3 EFS. The effects may be significant for some individual existing rights but in general are not dramatic.

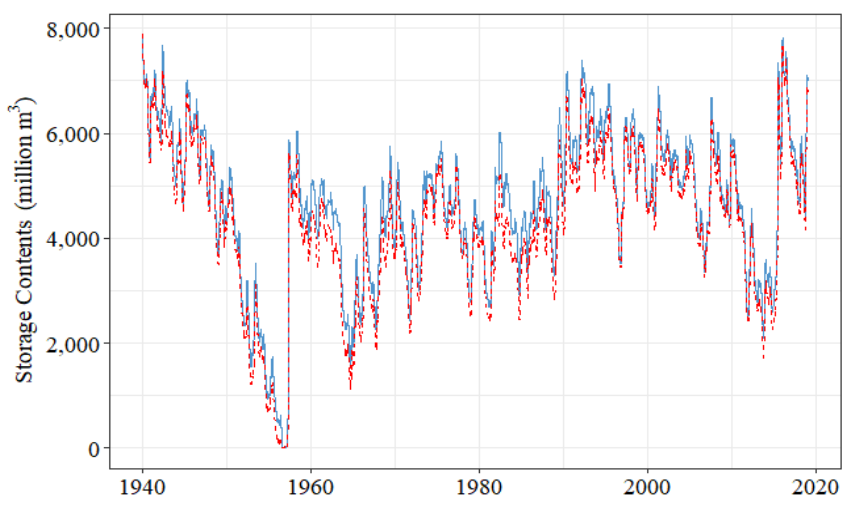

Figure 13 Summation of simulated storage contents of the 15 largest reservoirs in the Trinity WAM with low priority or no EFS (solid blue line) and high priority EFS (dashed red line).

WRAP-WAM simulated reservoir storage also provides a meaningful drought index. The simulation is based on the premise that 697 reservoirs and other existing constructed facilities are operated during a hypothetical repetition of 1940-2018 natural hydrology. All water users use the full amounts to which they are legally entitled, subject to water availability, throughout the 1940-2018 simulation. The most hydrologically severe drought to occur over the past $>100 \mathrm{y}$ for most of Texas began gradually in 1950 and ended dramatically in April-May 1957 with major wide-spread flooding. The 1950-1957 drought and April-May 1957 flood are evident in Figure 13. Although the 2010-2012 drought was economically very costly, the residents of the Trinity River basin have never experienced a drought as hydrologically severe as 1950-1957 with present population and water needs.

\subsection{Simulated regulated and unappropriated flows}

Frequency metrics for daily regulated and unappropriated flows at the four gauge sites are tabulated in Tables 9 and 10. The mean and standard deviation of the daily flow rates and the daily rates exceeded during specified percentages of the $28855 \mathrm{~d}$ of the 1940-2018 simulation are included in the tables. The 79 annual means of the observed flows, naturalized flows, simulated regulated and unappropriated flows, and low priority SB3 EFS limits at the Romayor site are compared in Figure 14.

Table 9 Frequency statistics for daily regulated flows.

\begin{tabular}{|c|c|c|c|c|c|c|c|c|}
\hline \multirow{3}{*}{$\begin{array}{l}\text { Gauge Site } \\
\text { SB3 EFS } \\
\text { Priority }\end{array}$} & \multicolumn{2}{|c|}{ Grand Prairie } & \multicolumn{2}{|c|}{ Dallas } & \multicolumn{2}{|c|}{ Oakwood } & \multicolumn{2}{|c|}{ Romayor } \\
\hline & $\begin{array}{c}\text { Lower } \\
\text { than }\end{array}$ & $\begin{array}{c}\text { Higher } \\
\text { than }\end{array}$ & $\begin{array}{c}\text { Lower } \\
\text { than }\end{array}$ & $\begin{array}{c}\text { Higher } \\
\text { than }\end{array}$ & $\begin{array}{c}\text { Lower } \\
\text { than }\end{array}$ & $\begin{array}{c}\text { Higher } \\
\text { than }\end{array}$ & $\begin{array}{c}\text { Lower } \\
\text { than }\end{array}$ & $\begin{array}{c}\text { Higher } \\
\text { than }\end{array}$ \\
\hline & existing & existing & existing & existing & existing & existing & existing & existing \\
\hline & rights & rights & rights & rights & rights & rights & rights & rights \\
\hline Flow Unit & $\left(\mathrm{m}^{3} / \mathrm{s}\right)$ & $\left(\mathrm{m}^{3} / \mathrm{s}\right)$ & $\left(\mathrm{m}^{3} / \mathrm{s}\right)$ & $\left(\mathrm{m}^{3} / \mathrm{s}\right)$ & $\left(\mathrm{m}^{3} / \mathrm{s}\right)$ & $\left(\mathrm{m}^{3} / \mathrm{s}\right)$ & $\left(\mathrm{m}^{3} / \mathrm{s}\right)$ & $\left(\mathrm{m}^{3} / \mathrm{s}\right)$ \\
\hline Mean & 15.3 & 17.4 & 41.1 & 45.8 & 120 & 183 & 183 & 189 \\
\hline Std Dev & 54.2 & 56.2 & 174 & 177 & 261 & 315 & 315 & 317 \\
\hline Minimum & 0.000 & 0.000 & 0.000 & 0.000 & 0.000 & 0.0762 & 0.0762 & 0.0745 \\
\hline $98 \%$ & 0.0894 & 0.0975 & 0.0857 & 0.0857 & 0.0890 & 0.0858 & 0.0858 & 0.0864 \\
\hline $95 \%$ & 0.109 & 0.124 & 0.0867 & 0.0872 & 0.116 & 2.83 & 2.83 & 3.56 \\
\hline $90 \%$ & 0.112 & 0.158 & 0.0901 & 0.0935 & 0.776 & 15.5 & 15.5 & 15.8 \\
\hline $80 \%$ & 1.12 & 1.58 & 0.121 & 0.371 & 13.8 & 40.7 & 40.7 & 43.2 \\
\hline $70 \%$ & 2.92 & 37.1 & 2.21 & 49.7 & 33.5 & 65.5 & 65.5 & 69.0 \\
\hline $50 \%$ & 7.17 & 8.91 & 10.2 & 15.0 & 85.7 & 140 & 140 & 153 \\
\hline $30 \%$ & 30.1 & 35.3 & 72.9 & 89.1 & 307 & 486 & 486 & 496 \\
\hline $10 \%$ & 1400 & 1420 & 4380 & 4480 & 5420 & 5670 & 5670 & 5340 \\
\hline Maximum & 15.3 & 17.4 & 41.1 & 45.8 & 120 & 183 & 183 & 189 \\
\hline
\end{tabular}

Table 10 Frequency statistics for daily unappropriated flows.

\begin{tabular}{|c|c|c|c|c|c|c|c|c|}
\hline Gauge Site & \multicolumn{2}{|c|}{ Grand Prairie } & \multicolumn{2}{|c|}{ Dallas } & \multicolumn{2}{|c|}{ Oakwood } & \multicolumn{2}{|c|}{ Romayor } \\
\hline SB3 EFS & $\begin{array}{l}\text { Lower } \\
\text { than }\end{array}$ & No SB3 & $\begin{array}{l}\text { Lower } \\
\text { than }\end{array}$ & No SB3 & $\begin{array}{c}\text { Lower } \\
\text { than }\end{array}$ & No SB3 & $\begin{array}{l}\text { Lower } \\
\text { than }\end{array}$ & No SB3 \\
\hline Scenario & existing & EFS & existing & EFS & existing & EFS & existing & EFS \\
\hline Flow Unit & $\begin{array}{l}\text { rights } \\
\left(\mathrm{m}^{3} / \mathrm{s}\right)\end{array}$ & $\left(\mathrm{m}^{3} / \mathrm{s}\right)$ & $\begin{array}{l}\text { rights } \\
\left(\mathrm{m}^{3} / \mathrm{s}\right)\end{array}$ & $\left(\mathrm{m}^{3} / \mathrm{s}\right)$ & $\begin{array}{l}\text { rights } \\
\left(\mathrm{m}^{3} / \mathrm{s}\right)\end{array}$ & $\left(\mathrm{m}^{3} / \mathrm{s}\right)$ & $\begin{array}{l}\text { rights } \\
\left(\mathrm{m}^{3} / \mathrm{s}\right)\end{array}$ & $\left(\mathrm{m}^{3} / \mathrm{s}\right)$ \\
\hline Mean & 2.58 & 3.67 & 42.3 & 8.13 & 42.3 & 47.9 & 126 & 144 \\
\hline Std Dev & 21.7 & 23.5 & 136 & 47.5 & 136 & 140 & 310 & 319 \\
\hline $50 \%$ & 0.000 & 0.000 & 0.000 & 0.000 & 0.000 & 0.0771 & 0.000 & 0.112 \\
\hline $40 \%$ & 0.000 & 0.000 & 0.0791 & 0.000 & 0.0791 & 0.130 & 4.14 & 25.2 \\
\hline $30 \%$ & 0.000 & 0.000 & 0.829 & 0.000 & 0.829 & 11.8 & 52.2 & 91.1 \\
\hline $20 \%$ & 0.000 & 0.0935 & 35.5 & 0.0961 & 35.5 & 52.9 & 164 & 216 \\
\hline $10 \%$ & 0.112 & 4.15 & 125 & 8.02 & 125 & 145 & 409 & 447 \\
\hline Maximum & 790 & 791 & 2880 & 1800 & 2880 & 2880 & 5615 & 5640 \\
\hline
\end{tabular}

The regulated flows generated by the simulation model are physical flows representing the premises reflected in the model. Unappropriated flows represent the portion of the flow still available for appropriation by additional new future water permit applicants after allocation of streamflow to all existing water rights. Unappropriated flows are less than regulated flows because a 
portion of the regulated flow may be passed through the site for higher priority water users located downstream and a portion of the regulated flow is committed to maintaining SB3 EFS.

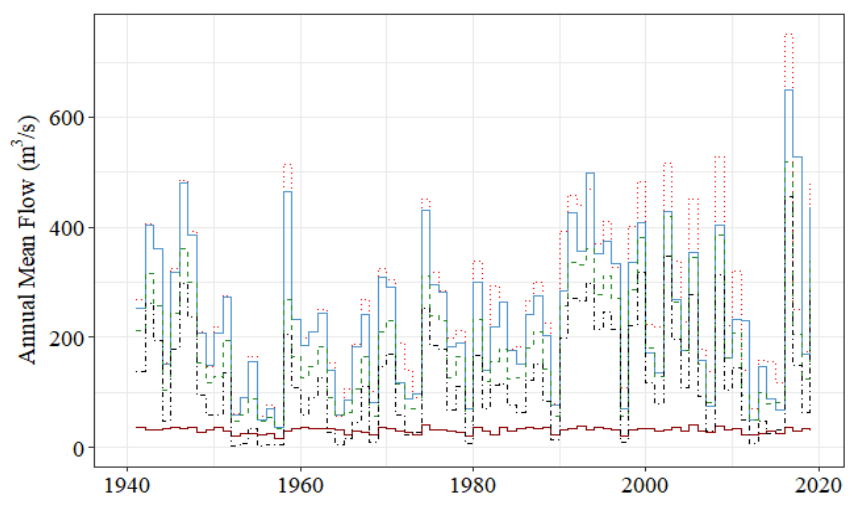

Figure 14 Annual means for observed (blue solid line), naturalized (red dotted line), regulated (green dashes), and unappropriated (black dashes and dots) flows and SB3 EFS (dark red solid line) for the Trinity River at Romayor.

The impacts of population and economic growth and associated water resources development are demonstrated by a comparison of the regulated and unappropriated flow statistics of Tables 9 and 10 with the naturalized flow statistics of Table 6 . Regulated flows are not affected by SB3 EFS with priorities lower than all other water rights in WAM. Table 9 also includes regulated flow statistics with SB3 EFS hypothetically assigned priorities higher than all other water rights, which demonstrates the effects of relative priorities on meeting water needs.

The effects of SB3 EFS on streamflow available for future new or amended water rights permits are shown by the statistics in Table 10 for unappropriated flows with and without SB3 EFS. Unappropriated streamflow occurs only during infrequent periods of high flows or floods. Thus, major additional reservoir storage capacity would be required to develop the remaining unappropriated streamflows for water supply.

\section{Conclusions}

Like most states in the western half of the United States, streamflow in Texas is allocated among competing users and uses based on the prior appropriation doctrine. A water rights permit system protects existing water users from being adversely affected by applicants for new water rights permits or amendments to existing permits. The state has implemented a WAM system to support water allocation, regional and statewide planning, operational planning, and other water management endeavours. Legislation enacted in 2007, Senate Bill 3, mandated establishment of environmental flow standards for priority river reaches statewide and incorporation of the EFS in the WAM system. New water rights permit applicants or amendments to existing permits are subject to the SB3 EFS.
The WAM system consists of the generalized WRAP modeling system, which can be applied to river or reservoir systems anyplace in the world, and simulation input datasets for all of the river basins of Texas. The version of WRAP routinely applied by the Texas water management community is based on a monthly computational time step. A daily WRAP with additional features for simulating environmental flow requirements and flood control reservoir operations has recently been developed to facilitate incorporation of SB3 EFS in the WAM system and integrated water management.

The WRAP-WAM system was combined with the IHA statistical analysis software package and other data management and analysis tools to assess flow alterations and impacts of SB3 EFS in the Trinity River basin as reported in this paper. These methodologies are demonstrated to efficiently generate relevant statistical metrics for the case study and are considered to be applicable for other river basins as well. The WRAP and IHA software and documentation are available for free download from websites maintained by the developers.

About $27 \%$ of the population of Texas resides in the upper Trinity River basin. Lake Livingston on the lower Trinity River, the largest reservoir in the basin, supplies water to Houston, which is the largest city in Texas, in an adjacent river basin. Flows of the Trinity River, like all Texas rivers, are extremely variable. Large dams and reservoirs are required to provide reliable water supply and reduce flooding. Flows of the Trinity River and its tributaries, except for flood flows, are almost entirely appropriated by existing water rights permit holders. Increases in water supply from remaining infrequent high flows requires construction of large volumes of additional reservoir storage capacity to achieve reasonable reliabilities. EFS have been established at four sites in the river system through the SB3 process.

Analyses presented in this paper quantify the impacts on the flows of the Trinity River of a century of continual rapid population and economic growth and accompanying water resources development. Median and mean flows have decreased. Long-term alterations include a decrease in flood flows by reservoir storage and increases in flows during dry periods due to return flows from water uses supplied from reservoir storage and groundwater, which are generally beneficial for environmental flow needs,

SB3 EFS have no impact on existing water users protected by the prior appropriation water rights permit system. The simulation study indicates that the impacts of SB3 EFS on water supply capabilities of existing water rights are generally relatively small even if SB3 EFS are hypothetically assigned higher priorities. SB3 EFS significantly reduce the already severely depleted remaining unappropriated flows.

\section{References}

Acreman, M. C., and M. J. Dunbar. 2004. “Defining Environmental River Flow Requirements- A Review." Hydrology and Earth 
System Sciences 8 (5): 861-76. https://doi.org/10.5194/hess8-861-2004.

Cheng, J., L. Xu, X. Wang, J. Jiang, and H. You. 2018. "Assessment of the Hydrologic Alteration Induced by Three Gorges Dam in Dongting Lake, China." Journal of River Research and Applications 34: 686-96. https://doi.org/10.1002/rra.3297.

Dewitz, J. 2019. “National Land Cover Database (NLCD) 2016 Products: U.S. Geological Survey data release." https://doi. org/10.5066/P96HHBIE.

Gao, Y., R. M. Vogel, C. N. Kroll, N. L. Poff, and J. D. Olden. 2009. "Development of Representative Indicators of Hydrologic Alteration." Journal of Hydrology 374 (1): 136-47. https://doi. org/10.1016/j.jhydrol.2009.06.009.

Gippel, C.J., M. Cosier, S. Markar, and C. Liu. 2009. “Balancing Environmental Flows Needs and Water Supply Reliability." International Journal of Water Resources Development 25 (2): 331-53. https://doi.org/10.1080/07900620902868802.

Hydrologic Engineering Center. 2009. “HEC-DSSVue HEC Data Storage System Visual Utility Engine, User's Manual Version 2." CPD-79, U.S. Army Corps of Engineers, Davis, California, USA. https://www.hec.usace.army.mil/software/hec-dss/ documentation/HEC-DSSVue 20 Users Manual.pdf.

Hydrologic Engineering Center. 2016. "HEC-SSP Statistical Software Package, User's Manual Version 2.1." CPD-86, U.S. Army Corps of Engineers, Davis, California, USA. https://www. hec.usace.army.mil/software/hec-ssp/documentation/HECSSP 21 Users Manual.pdf.

Jowett, I.G. 1997. "Instream Flow Methods: A Comparison of Approaches." Regulated Rivers: Research \& Management: An International Journal Devoted to River Research and Management 13 (2): 115-27. https://doi.org/10.1002/ (SICI) 1099-1646(199703)13:2<115::AID-RRR440>3.0.CO;2-6.

Lin, K., Y. Lian, X. Chen, and F. Lu. 2014. “Changes in Runoff and Eco-Flow in the Donhjiang River of the Pearl River Basin, China." Frontiers of Earth Science 8 (4): 547-57. https://doi. org/10.1007/s11707-014-0434-y.

Mathews, R., and B.D. Richter. 2007. “Application of the Indicators of Hydrologic Alteration Software in Environmental Flow Setting." Journal of American Water Resources Association 43 (6): 1400-13. https://doi.org/10.1111/j.17521688.2007.00099.x.

National Research Council. 2005. The Science of Instream Flows: A Review of the Texas Instream Flow Program. Washington, D.C.: National Academies Press. https://doi. org/10.17226/11197.

Nature Conservancy. 2009. “Indicators of Hydrologic Alteration (IHA) Software Version 7.1 User's Manual." https://www.conservationgateway.org/ConservationPractices/Freshwater/ EnvironmentalFlows/MethodsandTools/IndicatorsofHydrologicAlteration/Documents/IHAV7.pdf.

O’Keefe, J. 2012. “Chapter 4 Environmental Flow Allocation as a Practical Aspect of IWRM." In River
Conservation and Management edited by P. J. Boon and P. J. Raven. New Jersey: John Wiley \& Sons. https://doi. org/10.1002/9781119961819.ch4.

Opdyke, D.R., E.L. Oborny, S.K. Vaugh, and K.B. Mayes. 2014. "Texas Environmental Flow Standards and the Hydrology-Based Environmental Flow Regime Methodology." Hydrological Sciences Journal 59 (3-4): 820-30. https://doi.or g/10.1080/02626667.2014.892600.

Pal, S., A. Saha, and T. Das. 2019. "Analysis of Flow Modifications and Stress in the Tangon River Basin of the Barind Tract." Journal of River Basin Management 17 (3): 301-21. https://doi.org/10.1080/15715124.2018.1546714.

Paredes-Arquiola, J., F. Martinez-Capel, A. Solera, and V. Aguilella. 2013. “Implementing Environmental Flows in Complex Water Resources Systems - Case Study: the Duero River Basin, Spain." Journal of River Research and Applications 29: 451-68. https://doi.org/10.1002/rra.1617.

Pauls M.A., and R.A. Wurbs. 2016. “Environmental Flow Attainment Metrics for Water Allocation Modeling." Journal of Water Resources Planning and Management 142 ( 8). https:// doi.org/10.1061/(ASCE)WR.1943-5452.0000652.

Peres, D.J. ,and A. Cancelliere. 2016. “Environmental Flow Assessment Based on Different Metrics of Hydrologic Alteration." Journal of Water Resources Management 30 (15): 5799-817. https://doi.org/10.1007/s11269-016-1394-7.

Poff, N. L. and J. K. Zimmerman. 2009. “Ecological Responses to Altered Flow Regimes: A Literature Review to Inform the Science and Management of Environmental Flows." Freshwater Biology 55 (1): 194-205. https://doi.org/10.1111/j.13652427.2009.02272.x.

R Development Core Team. 2019. “R: A Language and Environment for Statistical Computing. R Foundation for Statistical Computing." Vienna, Austria. https://www.R-project.org/.

Richter, B.D., J.V. Baumgartner, J. Powell and D.P. Braun. 1996. "A Method for Assessing Hydrologic Alteration within Ecosystems." Conservation Biology 10 (4): 1163-74. https://doi. org/10.1046/j.1523-1739.1996.10041163.x.

Richter, B.D., J. V. Baumgartner, R. Wigington, and D.P. Braun. 1997. "How Much Water Does a River Need?" Freshwater Biology 37 (1): 231-49. https://doi.org/10.1046/j.13652427.1997.00153.x.

Texas Commission on Environmental Quality. 2011. “Environmental Flow Standards for the Trinity and San Jacinto Rivers and Galveston Bay. Texas Administrative Code Title 30, Part 1, Chapter 298, Subchapter B." Austin, Texas, USA. https://texreg.sos.state.tx.us/public/readtac\$sext.TacPage?sl=R\&app $=9 \& p$ dir $=\& p \quad r l o c=\& p \quad$ tloc $=\& p \quad p l o c=\& p-$ $\mathrm{g}=1 \& \mathrm{p}$ tac $=\& \mathrm{ti}=30 \& \mathrm{pt}=1 \& \mathrm{ch}=298 \& \mathrm{rl}=225$.

Texas Water Development Board. 2017. "Water for Texas 2017." Austin, Texas, USA. http://www.twdb.texas.gov/waterplanning/swp/2017/doc/SWP17-Water-for-Texas.pdf. 
Tharme, R.E. 2003. "A Global Perspective on Environmental Flow Assessment: Emerging Trends in the Development and Application of Environmental Flow Methodologies for Rivers." Journal of River Research and Applications 19 (5-6): 397-441. https://doi.org/10.1002/rra.736.

Wohl, E. 2019. “Forgotten Legacies: Understanding and Mitigating Historical Human Alterations of River Corridors." Water Resources Research, American Geophysical Union 55: 5181-201. https://doi.org/10.1029/2018WR024433.

Wurbs, R.A. 2005. "Texas Water Availability Modeling System." Journal of Water Resources Planning and Management 131 (4): 270-79. https:// doi.org/10.1061/(ASCE)0733-9496(2005)131:4(270).

Wurbs, R.A. 2006. "Methods for Developing Naturalized Monthly Flows at Gaged and Ungauged Sites." Journal of Hydrologic Engineering 11 (3): 55-64. https://doi.org/10.1061/ (ASCE)1084-0699(2006)11:1(55).

Wurbs, R.A. 2011. “Chapter 1 Generalized Models of River System Development and Management." In Current Issues in Water Management edited by U. Uhlig. London: InTech.

Wurbs, R.A. 2015. "Sustainable Statewide Water Resources Management in Texas." Journal of Water Resources Planning and Management 141 (12): A4014002-1-10. https://doi. org/10.1061/(ASCE)WR.1943-5452.0000499.

Wurbs, R.A. 2017. "Incorporation of Environmental Flows in Water Allocation in Texas." Water International 42 (1): 18-33. https://doi.org/10.1080/02508060.2016.1249246.

Wurbs, R.A. 2019a. "Fundamentals of Water Availability Modeling with WRAP." TR-283, 9th Ed., Texas Water Resources Institute, College Station, Texas. https://twri.tamu.edu/media/4123/ tr-283-9th-edition.pdf.

Wurbs, R.A. 2019b. "Water Rights Analysis Package (WRAP) River System Hydrology." TR-431, 3rd Ed., Texas Water Resources Institute, College Station, Texas. https://twri.tamu.edu/ media/4339/tr-431-3rd-edition.pdf.
Wurbs, R.A. 2019c. "Daily Water Availability Model for the Brazos River Basin and San Jacinto-Brazos Coastal Basin." TR-513, Texas Water Resources Institute, College Station, Texas. https://twri.tamu.edu/media/4215/tr-513.pdf.

Wurbs, R.A. 2019d. “Daily Water Availability Model for The Trinity River Basin."Texas Commission on Environmental Quality, Austin, Texas. https://ceprofs.civil.tamu.edu/rwurbs/wrap. htm

Wurbs, R.A. 2020. "Daily Water Availability Model for The Neches River Basin."Texas Commission on Environmental Quality, Austin, Texas. https://ceprofs.civil.tamu.edu/rwurbs/wrap. $\underline{\mathrm{htm}}$

Wurbs, R.A. 2021a. "Water Rights Analysis Package (WRAP) Modeling System Reference Manual." TR-255, 13th Ed., Texas Water Resources Institute, College Station, Texas, USA. https://twri.tamu.edu/media/4121/tr-255-12th-edition.pdf.

Wurbs, R.A. 2021b. “Water Rights Analysis Package (WRAP) Modeling System User's Manual." TR-256, 13th Ed., Texas Water Resources Institute, College Station, Texas. https://twri. tamu.edu/media/4122/tr-256-12th-edition.pdf.

Wurbs, R.A., and R.J. Hoffpauir. 2013. “Environmental Flows in Water Availability Modeling." TR-440, Texas Water Resources Institute, College Station, Texas. https://twri.tamu.edu/ publications/

Wurbs, R.A., and R.J. Hoffpauir. 2021. "Water Rights Analysis Package (WRAP) Daily Modeling System." TR-430, Texas Water Resources Institute, College Station, Texas. https://twri. tamu.edu/media/4124/tr-430-3rd-edition.pdf.

Yang, M.-Y. 2016. "Application of the Indicators of Hydrologic Alteration to Ecological Hydrology in Trinity and Brazos River Basins." Master of Science Thesis, Texas A\&M University, College Station, Texas, USA. 